\title{
SLEEP QUALITY AND SLEEP HABITS IN STUDENTS
}

\author{
Beatriz Almeida ${ }^{1}$; Carlos Albuquerque $^{2}$, Madalena Cunha ${ }^{2}, \&$ Anabela Antunes ${ }^{3}$ \\ ${ }^{1}$ Student, Project "Verão com Ciência", IPV-Higher School of Health, Viseu (Portugal) \\ ${ }^{2}$ Doctors Professors, IPV-Higher School of Health, Viseu, UICISA:E, CIEC - UMinho (Portugal) \\ ${ }^{3}$ Nurse, Centro Hospitalar Tondela-Viseu, Viseu (Portugal)
}

\begin{abstract}
Introduction: The student stage is marked by many changes that will affect different aspects of young youth life, including changes in sleep patterns. Sleep is known to play an active role in the overall development of students, mainly because of its restorative functions and an insufficient number of hours of sleep can be associated with consequences on physical and mental health.

Objectives: To analyze the factors that interfere with higher education students' sleep quality.

Methods: A systematic review of the literature was carried out drawing on a selection of articles published between 2012 and 2020, following the method proposed by the Joanna Briggs Institute and according to the Preferred reporting items for systematic reviews and meta-analyzes (PRISMA). This selection was carried out using PubMed, B-On and SCIELO search engines. The review was based on 5 articles whose methodological quality was found to be undeniable.

Results: Results show that, on the whole, students suffer from a poor quality of sleep. This situation is commonly associated with factors such as being a higher education student worker, shift work, or caffeine, alcohol, and tobacco use, among others.

Conclusions: In view of the outcomes, it became clear that higher education students need to be made more aware of the importance of sleep habits and daytime sleepiness, and to improve their health literacy. They need to be informed and trained in these areas so they may reduce or at least prevent certain risk behaviours that increasingly threaten their sleep quality and overall health.
\end{abstract}

Keywords: Students, sleep, sleep disorder, health, higher education.

\section{Introduction}

Sleep plays a complex role in a person's life and is essential to the life of every human being. The definition of normal sleep is subjective and complex. It is an important indicator of overall health and well-being and a basic biological need that has a strong impact on the quality and longevity of people's lives (Marques, 2017).

Students have to face several challenges when they enter higher education. They have to learn how to deal with different issues, including leaving home, increased independence, changes in peer groups, new social situations and maintenance of academic responsibilities, among others (Taylor, Bramoweth, Grieser, Tatum \& Roane, 2013). According to Schlarb, Bihlmaier, Hautzinger, Gulewitsch and Schwerdtle (2015), many students in higher education face special challenges and circumstances that are significantly associated with sleep disorders. About $60 \%$ of those students suffer from poor quality of sleep and $7.7 \%$ meet all the criteria for insomnia disorder. The study conducted by Schlarb, Friedrich and Claßen (2017) revealed that all university students are at risk of at least one sleep disorder.

Furthermore, they report that a minimum $7.7 \%$ of students suffer from insomnia and $24.3 \%$ from nightmares. These same authors state that sleep disorders and sleep problems severely impair higher education students' academic success. Sleep problems correlate with impeded learning, especially poorer declarative and procedural learning, neurocognitive performance, and academic success. Sleep problems have a major impact on the students' daily life due to irregular daytime routines, chronotype changes, side jobs and exam periods. In view of the above, this systematic review of the literature aims to analyze the factors that interfere with higher education students' quality of sleep.

${ }^{1}$ Corresponding Author; Carlos Albuquerque (cmalbuquerque@gmail.com) 
Following the issue under study, the research question was formulated according to the PI[C]OD methodology: Which factors will interfere with the sleep quality of higher education students?

\section{Method}

\subsection{Type of Study}

A systematic review of the literature was carried out in order to systematize current knowledge of the factors that may interfere with higher education students' sleep habits, in accordance with Preferred reporting items for systematic reviews and meta-analyzes (PRISMA) (Moher et al. 2009).

\subsection{Studies eligibility criteria}

Specific selection criteria were defined and applied to limit the number of articles to be included in the study, considering the existing inclusion and exclusion criteria (see Table 1).

Table 1. Studies inclusion and exclusion criteria.

\begin{tabular}{|l|l|l|}
\hline Selection criteria & Inclusion criteria & Exclusion criteria \\
\hline Participants & Higher education students & Age $\geq 18$ years old \\
\hline Interventions & Factors that influence sleep habits & $\begin{array}{l}\text { Studies that do not assess the } \\
\text { inclusion variable }\end{array}$ \\
\hline Comparisons & Unenforceable \\
\hline "Outcomes" & $\begin{array}{l}\text { Factors that interfere with higher } \\
\text { education students' sleep habits }\end{array}$ & $\begin{array}{l}\text { Studies that do not assess the } \\
\text { factors that interfere with higher } \\
\text { education students' sleep habits }\end{array}$ \\
\hline Type of study & $\begin{array}{l}\text { Experimental studies, quasi } \\
\text { experimental studies, analytical cross- } \\
\text { sectional studies, controlled clinical } \\
\text { trials, randomized studies, controlled } \\
\text { randomized trials, exploratory studies. }\end{array}$ & $\begin{array}{l}\text { Other designs that do not meet } \\
\text { the inclusion criteria }\end{array}$ \\
\hline
\end{tabular}

The following were also considered as inclusion criteria: date of publication between 2012 and 2020; articles written in Portuguese and English; article available full text.

\subsection{Resources used in the current study}

The studies were identified in accordance with the inclusion criteria defined and PubMed, B-On and SCIELO were the electronic database platforms of choice.

\subsection{Search strategy}

The following descriptors were used in conjunction with the Boolean operators: "Sleep" OR "Sleep Habits" [Entry Term(s)] AND "Sleep Disorders, Circadian Rhythm" [MeSH Major Topic] AND "Students" [MeSH Major Topic] AND "Education" [MeSH Major Topic] AND "Universities" [MeSH Major Topic] AND "college students" [Entry Term(s)]. Although the terms "Higher education", "Sleep Quality", "university students", "sleep characteristics", "sleep problems" and "sleep disturbances" are not MeSH descriptors, they were considered in the research as they are terms used in the specific literature. These descriptors, in Portuguese and English, were used through the different search engines to obtain full text articles.

\subsection{Studies selection}

56 articles were identified through the database search conducted. First, duplicate records were identified and removed $(n=14)$. In a second phase, the articles were analyzed $(n=42)$ through their titles and abstracts. 19 of them were excluded because they did not meet some of the inclusion criteria (date of publication, were not available full text and because of the language used), and 23 full text articles were assessed for eligibility. Of these, 18 were removed since they did not meet the remaining inclusion criteria. 5 studies made it to the final stage (see Figure 1). 
Figure 1. Diagram showing the selection procedure followed (PRISMA).

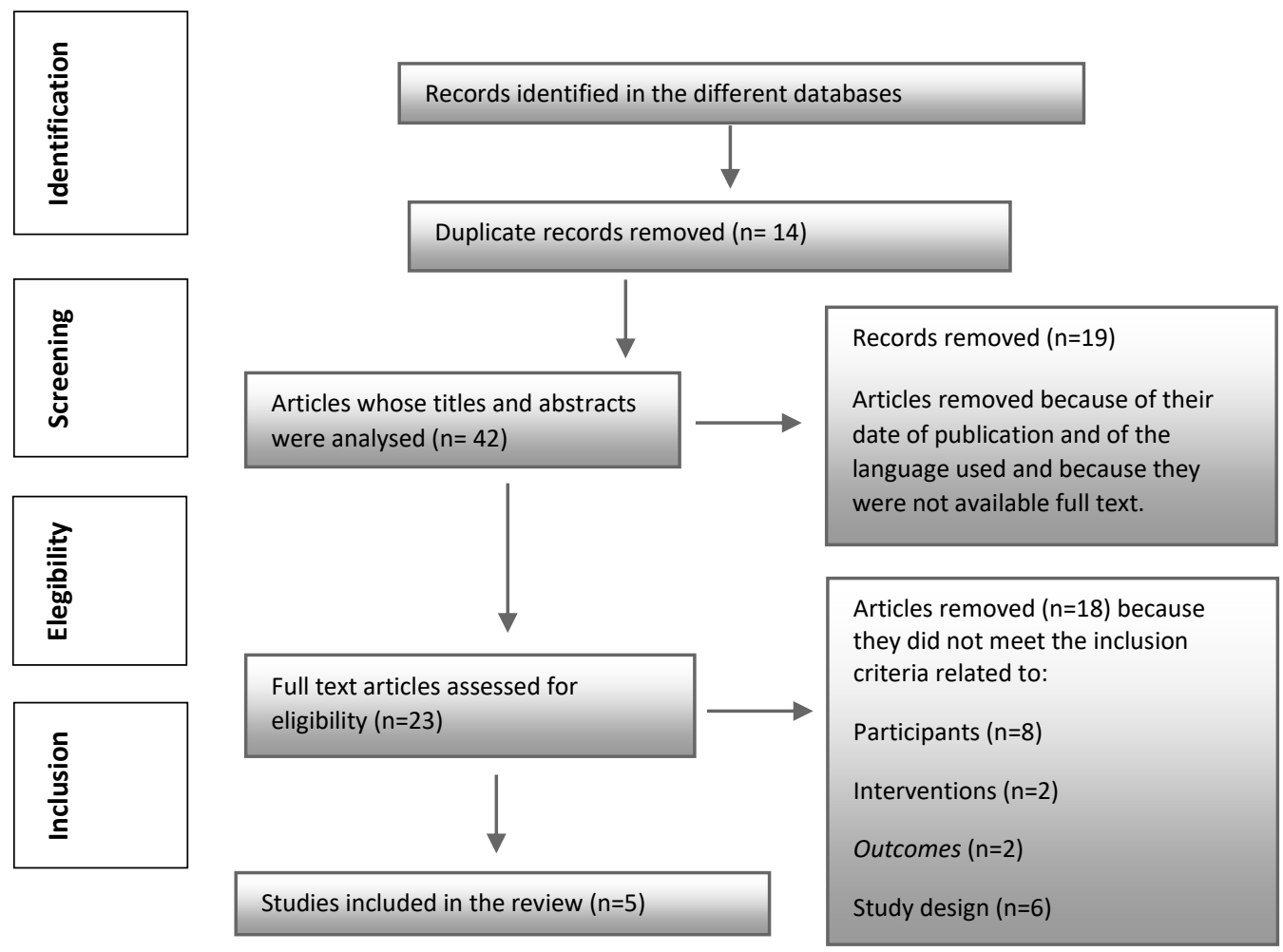

\section{Results}

The following table presents the characteristics of the articles that were included in the corpus of the review (table 2).

Table 2. Characteristics of the studies that became part of the corpus of the review.

\begin{tabular}{|c|c|c|c|}
\hline Studies & Participants & Type of study/interventions & Objectives \\
\hline $\begin{array}{l}\text { Martini, } \\
\text { Brandalize, } \\
\text { Louzada, } \\
\text { Pereira \& } \\
\text { Brandalize } \\
\text { (2012). }\end{array}$ & $\begin{array}{l}199 \text { students attending the } \\
\text { Physiotherapy course of a private } \\
\text { teaching institution in } \\
\text { Guarapuava - Brazil }\end{array}$ & $\begin{array}{l}\text { Quantitative, descriptive, and } \\
\text { cross-sectional study; the } \\
\text { Pittsburgh Sleep Quality Index } \\
\text { (IQSP) was used; environmental } \\
\text { /social and sociodemographic } \\
\text { variables. }\end{array}$ & $\begin{array}{l}\text { To analyze the sleep pattern of } \\
\text { university students attending the } \\
\text { physiotherapy course and the } \\
\text { factors associated with sleep } \\
\text { quality. }\end{array}$ \\
\hline $\begin{array}{l}\text { Mendes, Sousa, } \\
\text { Leite, Belchior } \\
\& \text { Medeiros } \\
(2019) \text {. }\end{array}$ & $\begin{array}{l}257 \text { higher education students } \\
\text { from seven higher education } \\
\text { institutions [Azores (Ponta } \\
\text { Delgada and Angra do Heroísmo) } \\
\text { and mainland Portugal (Oporto, } \\
\text { Lisbon, Coimbra, Leiria, Évora } \\
\text { and Minho) }\end{array}$ & $\begin{array}{l}\text { Quantitative, descriptive, and } \\
\text { cross-sectional study. The } \\
\text { Portuguese versions of the Sleep } \\
\text { Quality Index (PSQIPT) and the } \\
\text { Daytime Sleepiness Scale (ESS) } \\
\text { and a sociodemographic } \\
\text { questionnaire were applied }\end{array}$ & $\begin{array}{l}\text { To characterize the components } \\
\text { of subjective sleep quality and } \\
\text { excessive daytime sleepiness in } \\
\text { higher education students }\end{array}$ \\
\hline $\begin{array}{l}\text { Toscano- } \\
\text { Hermoso, } \\
\text { Arbinaga, } \\
\text { Fernández- } \\
\text { Ozcorta, } \\
\text { Gómez-Salgado } \\
\text { \& Ruiz-Frutos } \\
(2020) \text {. }\end{array}$ & 855 university students & $\begin{array}{l}\text { Ex post facto study. } \\
\text { The following instruments were } \\
\text { applied: the Pittsburgh Sleep } \\
\text { Quality Index (IQSP), Nightmare } \\
\text { Proneness Scale; Composite } \\
\text { Scale of Morningness }\end{array}$ & $\begin{array}{l}\text { To analyze, according to the } \\
\text { gender of the students, } \\
\text { possible sleep-related differential } \\
\text { patterns }\end{array}$ \\
\hline $\begin{array}{l}\text { Araújo, Lima, } \\
\text { Thiago, Veras, } \\
\text { Zanetti \& } \\
\text { Damasceno } \\
\text { (2014) }\end{array}$ & $\begin{array}{l}701 \text { students from Fortaleza, } \\
\text { Brasil. }\end{array}$ & $\begin{array}{l}\text { Cross-sectional study. } \\
\text { A Sociodemographic Form and } \\
\text { the Pittsburgh Sleep Quality } \\
\text { Index (IQSP) were applied }\end{array}$ & $\begin{array}{l}\text { To analyze the relationship } \\
\text { between socio-demographic } \\
\text { variables and the poor sleep } \\
\text { quality of Brazilian university } \\
\text { students }\end{array}$ \\
\hline $\begin{array}{l}\text { Okano, } \\
\text { Kaczmarzyk, } \\
\text { Dave et al. } \\
(2019)\end{array}$ & 493 Dutch university students & $\begin{array}{l}\text { Cross-sectional study. } \\
\text { The Pittsburgh Sleep Quality } \\
\text { Index (IQSP) was used }\end{array}$ & $\begin{array}{l}\text { To study the individual and social } \\
\text { factors associated with } \\
\text { unsatisfactory sleep and its } \\
\text { consequences on higher } \\
\text { education students }\end{array}$ \\
\hline
\end{tabular}




\section{Discussion and conclusion}

The results reveal that, on the whole, higher education students show poor sleep quality and that this fact is related to factors like being a student worker, working shifts, or to the consumption of caffeine, alcohol and tobacco. Sleep disorders seem to be associated, according to Mendes et al. (2019, p. 45), "with physical and psychological consequences and, in the long term, can become a public health problem". On the other hand, studies show that the right quantity and quality of sleep seems to be associated with more positive academic results in higher education students

Higher Education Institutions are capital places for the promotion of healthy habits, therefore the results obtained justify the implementation of sleep education programmes aimed at students, following the premise that if students are provided with the right knowledge, they will be able to make healthier choices by changing their behaviour. We believe that this type of sleep education programmes will make students aware of the importance of sleep-wake cycles, demonstrating that the knowledge to be acquired can be useful not only to improve their sleep quality, but also to provide them with the right tools to encourage and stimulate healthy sleep habits. Investing in good sleep habits is investing in the future. It is therefore important to provide students with a set of healthy sleep rules and practices that will enable them to develop empowerment and help them promote their health.

\section{Acknowledgements}

This work is financed by National Funds through FCT -- Fundação para a Ciência e a Tecnologia, and DGES under the initiative Summer School with Science "Dynamics and implementation of inclusion for health promotion and literacy in higher education" and the project:"iPV with Health Plus", reference: PROJ/IPV/ID\&I/005. The authors would like to extend particular thanks to the Polytechnic Institute of Viseu for its support.

\section{References}

Araújo, M.F.F.M. de, Lima, A.C.S.A., Thiago, M de, Veras, V.S., Zanetti, M.L., \& Damasceno, M.M.C. (2014). Association of sociodemografic factors and sleep quality in brazilian university students. Texto \& Contexto - Enfermagem, 23(1),176-184. https://doi.org/10.1590/S010407072014000100021

Marques, J.A.C.P. (2017). Qualidade de Sono de Adolescentes em Contexto Escolar (Dissertação de Mestrado). Escola Superior deEnfermagem de Coimbra.

Martini, M., Brandalize, M., Louzada, F.M., Pereira, É.F. \& Brandalize, D. (2012). Fatores associados à qualidade do sono em estudantes de Fisioterapia. Fisioterapia e Pesquisa, 19(3), 261-267. https://doi.org/10.1590/S1809-29502012000300012

Mendes, J., Sousa, M., Leite, V.M., Belchior, N., \& Medeiros, T. (2019). Qualidade do sono e sonolência em estudantes do ensino superior. Revista Portuguesa de Investigação Comportamental e Social; Vol. 5 (2), 38-48. In: http://repositorio.ismt.pt/bitstream/123456789/1128/1/150-Texto\%20Artigo1247-1-10-20191130.pdf

Moher, D. , Liberati, A., Tetzlaff, J. Altman, D. (2009). Preferred reporting items for systematic reviews and meta-analyses: the PRISMA statement. BMJ 2009; 339 doi: https://doi.org/10.1136/bmj.b2535

Okano, K., Kaczmarzyk, J.R., Dave, N. et al. (2019). Sleep quality, duration, and consistency are associated with better academic performance in college students. npj Sci. Learn.; 4, 16. https://doi.org/10.1038/s41539-019-0055-z

Schlarb, A.A., Bihlmaier, I., Hautzinger, M., Gulewitsch, M.D., \& Schwerdtle, B. (2015). Nightmares and associations with sleep quality and self-efficacy among university students. J Sleep Disord Manag.; 1(2), 1-5. In: https://clinmedjournals.org/articles/jsdm/journal-of-sleep-disorders-and-managementjsdm-1-006.pdf

Schlarb, A.A., Friedrich, A., \& Claßen, M. (2017). Sleep problems in university students - an intervention. Neuropsychiatric Disease and Treatment; 13, 1989-2001. Acedido em https://www.ncbi.nlm.nih.gov/pmc/articles/PMC5536318/pdf/ndt-13-1989.pdf

Taylor, D.J., Bramoweth, A.D., Grieser, E.A., Tatum, J.I., \& Roane, B.M. (2013). Epidemiology of insomnia in college students: relationship with mental health, quality of life, and substance use difficulties. Behav Ther.; 44(3), 339-348. doi:10.1016/j.beth.2012.12.001. Epub 2012 Dec 19. PMID: 23768662.

Toscano-Hermoso, M.D., Arbinaga, F., Fernández-Ozcorta, E.J., Gómez-Salgado, J., \& Ruiz-Frutos, C. (2020). Influence of Sleeping Patterns in Health and Academic Performance Among University Students. Int. J. Environ. Res. Public Health; 17, 2760. doi:10.3390/ijerph17082760 